UDC 37.016:81’373.72:811.111:[94:028.7](045)=111

DOI https://doi.org/10.24919/2308-4863/43-1-32

Natalia HERTSOVSKA, orcid.org/0000-0003-0971-7529

Candidate of Philology, Associate Professor, Associate Professor at the Department of English Language, Literature with Methodology of Teaching

Mukachevo State University (Mukachevo, Transcarpathian region, Ukraine) nataliyahertsovska@gmail.com

\author{
Tetiana SHPENYK, \\ orcid.org/0000-0001-8031-7187 \\ a second-year master's student at the Faculty of Humanities \\ Mukachevo State University
}

(Mukachevo,Transcarpathian region,Ukraine) tatjana.shpenik@privatbank.ua

\title{
THE IMPORTANCE OF HISTORICAL EXCURSUS IN TEACHING ENGLISH IDIOMS
}

The article considers the importance and necessity of using historical excursus in the study of English idioms. Usually idioms have the meaning which is different from the words that make it up and, thus, they appear to be quite a difficult task, for both - teachers, in terms of using special teaching methods, and for pupils and students. Modern English has a large number of idioms that are closely linked to the history, culture and traditions of the native speakers.

The vast majority of scholars who have studied the problems of English idioms in their works, support the approach to learn idioms by methods that would promote their effective study and appropriate usage, taking into account the cultural values, mentality of the native language of those who study the idioms.

Taking into account the immensity of sources of various information, there arise new requirements to the modern teacher, including the knowledge and subjects that go beyond linguistics, but in some respect having common points of study (history, language culure study, geography). The use of historical excursus $n$ the study of English idioms, brings the learning process to a new, qualitatively higher level; allows to involve additional tools and teaching methods; acts as a kind of catalyst that stimulates the processes of both the discussion of idioms and their subsequent use in language as a whole.

Systematic work with idioms through the prism of historical excursus allows students to change their point of view and consider cultural realities and traditions from the standpoint of native speakers of the English language. The knowledge of idioms associated with interesting historical events, facts, legends, personalities, does not only explain their meaning, but also significantly expands the worldview and enrich the language and conceptual picture of the world of students learning English.

Key words: idiom, historical excursus, methods and principles of teaching idioms, origin of idioms, meaning of idioms, language picture of the world, conceptual picture of the world.

Наталія ГЕРЦОВСЬКА, orcid.org/0000-0003-0971-7529 кандидат філологічних наук, доцент, доиент кафедри англійської мови, літератури з методиками навчання

Мукачівського державного університету (Мукачево, Закарпатська область) nataliyahertsovska@gmail.com

Тетяна ШПЕНИК, orcid.org/0000-0001-8031-7187 студентка II курсу магістратури гуманітарного факультету Мукачівського державного університету (Мукачево, Закарпатська область) tatjana.shpenik@privatbank.ua

\section{ВАЖЛИВІСТЬ ІСТОРИЧНОГО ЕКСКУРСУ В НАВЧАННІ АНГЛІЙСЬКИХ ІДІОМ}

У статті розглянуто важливість та необхідність використання історичного екскурсу під час вивчення англійських ідіом. Зазвичай ідіоми мають значення, відмінне від слів, щңо його утворюють, тому є досить складним завданням як для вчителів, з точки зору методики їх навчання, так і для учнів та студентів. Сучасна англійська мова налічує велику кількість ідіом, щуо тісно пов'язані з історією, культурою і традиціями носіїв мови. 
Більшість науковців, які у своӥх прачях досліджували проблематику англійських ідіом, підтримують думку про необхідність вивчення ідіом за методами, які б сприяли їх ефективному вивченню та доречному використанню, враховуючи культурні иінності, менталітет та особливості рідної мови учнів.

В умовах неосяжності джерел різної інформації до сучасного педагога висуваються нові вимоги, як-от володіння знаннями і предметами, шчо виходять за межі лінгвістики, проте в деяких аспектах мають спільні точки дотику (історія, країнознавство, географія). Використання історичного екскурсу під час вивчення англійських ідіом виводить процес навчання на якісно вищий щуабель; дозволяє залучати додаткові інструменти, методики викладання; є каталізатором, що стимулює як процеси самого обговорення ідіом, так і подальще їх використання у мові загалом.

Систематична робота з ідіомами через призму історичного екскурсу, дає змогу учням змінити кут зору $i$ розглянути культурні реалії і традиції з позиції носіїв цієї мови. Знання ідіом, пов'язані з цікавими історичними подіями, фактами, легендами, особистостями, не лише дозволяє пояснити їх зміст, а й значно розширюють світогляд та збагатити мовну та концептуальну картину світу учнів та студентів, які вчать англійську.

Ключові слова: ідіома, історичний екскурс, методи і принципи навчання ідіом, походження ідіом, значення ідіом, мовна картина світу, концептуальна картина світу.

Defining the problem. Classification of English idioms is an important issue of many scientific investigations. While dealing with idioms the main tasks are as follows: translating, understanding and using. In English there are many idioms which have full or partial Ukrainian analogues. At the same time there is a large number of idioms that do not have Ukrainian analogues, which are difficult to translate. Idioms related to history, interesting legends not only explain the essence and content of the phrase, but also acquaint with interesting historical facts, expand the worldview, go beyond linguistics.

From another point of view, in the present-day globalized society the achievements of scientific and technological progress are unquestionable, they influence all spheres of vital activity and linguistic processes, cause new terms, expressions, phrases to appear, that reflect reality of modern society and change teaching process as well.

Nowadays the qualities of a good teacher include skills in communication, listening, collaboration, adaptability, empathy and patience. Other characteristics of effective teaching include an engaging classroom presence, value in real-world learning, exchange of best practices and a lifelong love of learning. Effective teachers demonstrate a deep understanding of the curriculum and knowledge of other subjects connected with English, such as history, geography, language culture study, etc. In this respect the knowledge and correct usage and explanation of idioms would be of a great value for English teachers.

Classification of English idioms appear the object of investigation in the works of A. Aljochina, M. Basai, R. Ekkert, M. Leonidova, O. Smirnitskuj, S. Skorupka. Specialties of English idioms in translation have been analyzed by O.Kurilko and G. Sidoruk. Morphological classification of idioms in English and Armenian has been highlighted by A. Hovhannisyan, R. Ghazaryan. In these works the authors deal with different approaches to classification, description of idioms, in consequence of they recognize the difficulties and struggling connected with translating, teaching, understanding, and appropriate using of English idioms for foreign learners.

Aim and tasks. In our research we are aimed to reveal historical and traditional English idioms from the point of view of historical excursus. For this purpose, we considered some of the most interesting historical idioms according to their history of origin and occurrence. Some idioms may appear so unusual that it is impossible to guess their origin, just in case you know the history. Therefore to better understand the ways of correct using of idioms, to allow deeper immersion in the atmosphere of the native speakers the following tasks are to be solved:

Presentation of the material. Every language in the world, with modern English is not an exception, has the phrases that, though consisting of well-known words, convey quite a different meaning than the one prescribed by these words. According to Oxford dictionary, an idiom refers to a group of words fixed by usage as having a meaning not deducible from those of the individual word (McCarthy, 2002).

Development of the English language is characterized by the accumulation of a large amount of idioms, which emotionally color and enrich speech and communication, in addition idioms allow reducing complicate sentences to simple constant expressions. In relation to the period of their occurrence idioms can be classified into traditional, which were used for a long period of time, and modern, which have emerged relatively recently. The latest idioms can be traced back as far as 3,000 years. All idioms - from the ancient to the most recent - owe their creation to the development of human thought and language evolution. In English there are idioms borrowed from Celtic, Latin, Scandinavian, French, German and other cultures such as Spanish, Portuguese, Danish, Indian and Chinese. The whole history of Great Britain is 
divided into periods: prehistory, Roman Britain, Anglo-Saxon period, Norman England, England after Plantegenets, Tudor England, 17th century, formation of Great Britain and the United Kingdom, modern England (18th - 19th centuries), late modern (20th century) and contemporary. We are inclined to think that traditional idioms are those which arose to 19th century (Voevoda, 2009).

One of the oldest idiom is "Cloud Cuckoo Land" which tells us about a state of absurdly over-optimistic fantasy. It was firstly accredited to "The Birds", a play, a comedy written by ancient Greek playwright Aristophanes, performed in ancient Athens in 414 BC.

According to the history of origin there are ranges of idioms connected to history of Great Britain. Such idioms recover the peculiarity of thinking British, their mentality, public relationship, acquired values, and accumulated experience centuries ago. Let us consider some traditional English idioms: "To hand over the reins»: rein is a long, thin piece of leather or other material that is used to control or direct a horse. The meaning of idiom is to take or give someone control over an organization or country.

An idiom «to add fuel to the fire» is to make an argument or bad situation worse. The idiom can be traced back to the ancient Rome and "The history" of Titus Livius who lived around I cent.: "Not withstanding my remonstrance, you have added fuel to this fire, by sending to your army a youth who burns with an ambition of sovereignty...". A wellknown idiom "to carry coals to Newcastle" was first documented in North America in 1679 in William Fitzhugh's letters. It refers to the fact that historically, the economy of Newcastle upon Tyne in north-eastern England was heavily dependent on the distribution and sale of coal and therefore any attempt to sell coal to Newcastle would be foolhardy as supply would be greater there than anywhere else in Britain (Sherik, Savichuk, Starko, 2005).

Probably the most widely used idiom by Ukrainian learners is: "to rain cats and dogs", though the origin of it is not so spread. The phrase has been used at least since the 17th century. One possibility that is the expression comes from the poorly built streets of England during the 1600's. When a heavy rain came, the streets were flooded by flowing sewage and trash. Any dogs and cats trapped in the muck could easily be killed. Hence, after a very bad rain, the corpses of cats and dogs were often found outside, looking as if they fell from the sky. Thus, the idiom was born.

The term "dead as doornail" firstly was used in the 1500 s by William Shakespeare, and in Charles Dickens' "A Christmas Carol" in 1843. Doornails are the large-headed studs that were used in earlier times for strength and more recently as decoration. The practice was to hammer the nail through and then bend the protruding end over to secure it. This process, similar to riveting, was called clenching. This may be the source of the 'deadness', as such a nail would be unusable afterwards.

There are a plethora of sayings relating to alcohol and the Dutch. During the $17^{\text {th }}$ century, the Netherlands and Britain squabbled for control of marine trade routes. They waged three wars against each other over 20 years. When the English and the Dutch were trying to mining it over the rest of the world, the English tried to smear the competition by cowardly and disdain everything "Dutch". Most idioms about the Dutch in the English language came into being after 1665. In the English language at these days preserved many idioms involving "Dutch", for example: "beat the Dutch" - to exceed expectations, "Dutch act / cure" - committing suicide, "Dutch agreement" - an agreement made while intoxicated, "Dutch bargain" - a bargain settled over drinks, "I'm a Dutchman if I do" - a strong refusal, "If not, I'm a Dutchman" - used to strengthen an affirmation or assertion (Sherik, Savichuk, Starko, 2005: 161).

Another interesting idiom containing a proper name is "Queen Anne is dead!" which is sarcastic way of saying: "That's old news. I heard that weeks ago". The death of Queen Anne was officially hushed up for a while. News had leaked out, so when at last there was an official announcement of the Queen's death, the crowd chanted in derision "Queen Anne is dead - didn't you know?" and to this day "And Queen Anne is dead" is a standard rejoinder to somebody who bears stale news or states the obvious.

Human emotions are different and therefore can be differently applied to in idioms. Idioms are usually derived from local culture and customs in each individual language. In the process of historical development people have been trying to express their emotions, feelings, relationship by using idioms. "A penny for your thoughts" is used to ask what someone is thinking about. First used by English statesman Sir Thomas More in his 1522 book Four Last Things, the idiom "A penny for your thoughts" has retained the same meaning for nearly 500 years.

"To have a heart of gold" means to be of a generous nature. It comes from the idea of gold being a precious metal that is highly valued. The use of this idiom dates back at least to the 1500s. The expression was already in use during Shakespeare's time, when he included it in his play "Henry V". It appears in a scene in which the king has disguised himself as a commoner. "A wet blanket" is a person who discourages enjoyment or enthusiasm, someone who dampens other people's 
joy. The expression dates from around the 1870 s and is based on the fact that cooks at that time kept a wet blanket in the kitchen to smother fires quickly. This practice dates back at least to the mid-1600s. "Give the shirt off back" is to lose a majority of one's wealth or value in an investment. This phrase implies not just loss, but ultimate loss. This hyperbolic idiom was first recorded in 1771 (Engblog).

The term "spitting image" is the exact double of another person or thing, is an allusion to someone who is so like someone else as to appear to have been spat from his mouth. The concept and phrase were in circulation by 1689, when George Farquhar used it in his play Love and a Bottle: "Poor child! He's as like his own dada as if he were spit out of his mouth". "To wear the pants" is be the dominant partner in a relationship. This idiom, generally applied to women and dating from the mid-1500s, a time when they wore only skirts, equates pants with an authoritative and properly masculine role. "To cook someone's goose" is to make it certain that someone will fail or lose. The most commonly written about origin is that when a man called Jan Hus (an early 15th Century religious reformer) was on his death bed and proclaimed that the goose would now be cooked. In English there are many idioms related to money, success, and entertainment.

"Two sides of the same coin" which reflect such purely cultural aspects of the life of nation, mean that are two things that are regarded as two parts of the same thing. The proverb has been traced back in English to 1742, and is first attested in the United States in the 1802 «Diary and Autobiography of John Adams» and an 1817 letter of Thomas Jefferson.

"Keep the wolf from the door" is to have or earn enough money to afford things (such as food and clothing) that is needed to live. The original saying may have been keep the wolf from the gate, which dates from at least 1470. By the 1500s the saying had become keep the wolf from the door, with the current meaning that it bears: see, for example, the 1645 quotation. "To make one's blood boil" means to make someone very angry. Enrage one, as in Whenever Jim criticizes his father, it makes my blood boil. Although this term did not appear in print until 1848, the term the blood boils, meaning "one gets angry" dates from the 1600 s.

There is a wide range of idioms related to theme time, which indicate and reflect social norms, beliefs, attitudes, and emotions. "Dog days of the summer" is the period between early July and early September when the hot sultry weather of summer usually occurs in the northern hemisphere; a period of stagnation or inactivity. When Sirius would appear in the sky just before the sun, near the end of July, which marked the beginning of the very hottest days of the year. The
Romans referred to this period as "dies caniculares" or "days of the dog star", which was eventually translated as just "dog days". "Indian summer" is a period of unseasonably warm, dry weather that sometimes occurs in autumn; the exact origins of the term are uncertain, it was perhaps so-called because it was first noted in regions inhabited by Native Americans, or because the Natives first described it to Europeans, or it had been based on the warm and hazy conditions in autumn when Native Americans hunted (Engblog).

As around 150,000 words of the English language are derived from ancient Greek, it should come as no surprise then, that many sayings and idioms also have their roots in ancient Greek. The majority of English sayings with Greek origins have emerged from ancient Greek myths and stories, and they have full or partial Ukrainian equivalents. Here are some of the most used English sayings and phrases with a decidedly Greek touch: "Achilles heel" - someone's weak spot. As a baby, Achilles' mother, Thetis, dunked him in the River Styx, said to have the magical power of making people invulnerable, by holding him upside down by his heel. Consequently, Achilles' heel was the only part of his body to be kept dry, and, as it turns out, vulnerable, it was at this spot, according to Homer, in his work, The Iliad, a poison arrow, launched by Paris, one of the Trojans, hit Achilles, killing him instantly.

"Beware of Greeks bearing gifts, the Trojan Horse" is a phrase from Aeneid written by Virgil between 29 and 19 BC, is the Trojan priest Laocoon's warning, meaning beware of Greeks bearing gifts, used today as a warning to be careful about accepting gifts from enemies or opponents, because, you never know what may be lurking inside. The Trojans, fighting against the Greeks during the ten-year Trojan war (10-12 century $\mathrm{BC})$, had learnt, to their detriment, the dangers of accepting gifts from the Greeks. The Greeks, who had besieged the city of Troy, pretended to retreat, leaving behind them, outside the gates of the city, a large wooden horse. The Trojans, assuming they had won the war, and thinking the horse a gift, brought it inside the city, but those wily Greeks had hidden soldiers inside the horse, who sneaked out in the night, and captured the city of Troy (Greeker than the Greeks).

"The Midas Touch" is said about someone who has a great success in financial dealings, someone who succeeds in anything he/she puts his/her hand to, whatever he/she touches, turns to gold. The saying comes from the Greek myth about Midas, the greedy king of Phrygia, in Asia Minor, who was granted a wish by Dionysus, god of the grape-harvest, winemaking and wine, of fertility, ritual madness, religious ecstasy. Midas wished for everything he touched, to turn to gold, 
if only he had given more thought to his wish, literally, everything he touched, turned to solid gold, food, water, wine, and most sadly of all, his precious daughter Zoe. A true case of be careful what you wish for.

"Between a rock and a hard place" - this particular idiom from Greek mythology is the one you will hear quite frequently in English. If someone is stuck between a rock and a hard place, they have a very difficult decision to make. "Call a spade a spade" is used to address or describe the true nature of someone or something, even if it is unpleasant or impolite. "Herculean task" - meaning the task requiring the great strength of a Hercules which very hard to perform. "Pandora's Box" is a process that once begun generates many complicated problems. "Leave no stone unturned" - to make every possible effort to find someone or something (Greeker than the Greeks).

The Bible is the holy scripture of the Christian religion, purporting to tell the history of the Earth from its earliest creation to the spread of Christianity in the first century A.D. Other words the Bible is the ground of religions Christianity in Europe. The Bible was translated into English and all language in the world hundreds of years ago. Majority Hebrew or Greek idioms have become part of many languages in the world, with the English and Ukrainian not an exception. The Bible's Old Testament is very similar to the Hebrew Bible, which has origins in the ancient religion of Judaism. The exact beginnings of the Jewish religion are unknown, but the first known mention of Israel is an Egyptian inscription from the 13th century B.C. The Bible was first written in Hebrew and then translated into Greek and many idioms used in both of them (Biblical idioms and sayings with origins explained).

We want to pay attention on the Biblical idioms which being tightly connected with Ukrainian mentality, are common, popular and often used: "The blind leading the blind" refers to a situation where people lacking in skill or knowledge are being led or guided by others who are equally inept (Origin: Matthew 15:13-14). "Money is the root of all evil" means that greed is the cause of a particular problem or the cause of society's problems in general (Origin: 1 Timothy 6:10). "A sign of the times" is something that is typical of the way that things are now, generally in a negative way (Origin: Matthew 16:3). "There's nothing new under the sun" is a way of saying that everything has been seen before; there is nothing new or original these days (Origin: Ecclesiastes 1:9). "Wolf in sheep 's clothing" someone who is pretending to be something they are not, usually to the detriment of others. (Origin: Matthew 7:15) (Biblical idioms and sayings with origins explained).

Conclusions. Idioms are highly interactive items; they are strong and colorful examples of crosscultural relations; idioms are omnipresent in natural human language and all languages use idioms to express the realities of daily life. Knowing culture, literature and traditions of different nationalities will help the language learner to communicate with a native speaker adequately.

Traditional methods of teaching idioms focus on rote learning and memorization. Recent developments in cognitive linguistics have considered idioms as analyzable expressions which are motivated by conceptual metaphors and whose meanings can derive from associations between source and target concept. There are a few main arguments in favor of teaching idioms by means of historical excursus: offering students systematic opportunities to encounter idioms during their language training therefore enables them to acquire new perspectives on life, viewing different cultural realities through the eyes of the people who create and use these turns of phrase; the process of teaching idioms permits using additional tools, such as an immersion in British atmosphere, their tradition, legendy and culture; oftentimes, the etymological origins and historical exurcus of fixed, institutionalized idiomatic expressions reveal important information about their metaphorical register and imagery; language practitioners are therefore strongly encouraged to make etymological information available to students at all levels, and to use this as a catalyst for further discussion about an idiom's figurative meaning and its purpose in communication.

The analyzed idioms are implied in every day speech, what is they might be easily inserted in the process of everyday communication of the learners of English. The using of idioms in the teaching process and in the different communicative situations is the best reason and the unique opportunity to teach both language and culture from a multitude of sociocultural perspectives, leading to learners' development and attainment of idiomatic competence. Through idiomatization, pupils and students develop and attain high levels of communicative competence, and in such way they use language in socially responsible way, having enriched their language and conceptual pictures of the world.

\section{BIBLIOGRAPHY}

1. Воевода Е.В. Великобритания: история и культура = Great Britain: Culture across History : учеб. пособие. Москва : МГИМО-Университет, 2009. 223 с. 
2. Шерік А.Д., Савічук В.Я., Старко В.Ф. Довідник англійських, німецьких та українських ідіом та виразів. Київ : Видавничий дім «Києво-Могилянська академія», 2005. 173 с.

3. Biblical idioms and sayings with origins explained: web-site. URL: https://improving-your-english.com/vocabulary/ idioms/bible-idioms/

4. Engblog. Для изучающих английский язык: web-site. URL: https://engblog.ru/origins-of-idioms

5. Greeker than the Greeks: web-site. URL: https:/greekerthanthegreeks.com/2019/04/20-everyday-english-phrasessayings-and-idioms-with-greek-origins.html

6. McCarthy M. Cambridge International Dictionary of Idioms. Cambridge University Press, 2002. 604 p.

\section{REFERENCES}

1. Voevoda E.V. Velikobritaniya: istoriya i kultura [Great Britain: Culture across History] : ucheb. posobie. M. : MGIMOUniversitet. 2009. 223 s. [in Russian]

2. Sherik A.D., Savichuk V.Ia., Starko V.F. Dovidnyk anhliiskykh, nimetskykh ta ukrainskykh idiom ta vyraziv. [Handbook of English, German and Ukrainian idioms and expressions]. K.: Vydavnychyi dim «Kyievo-Mohylianska akademiia». 2005. 173 s. [in Ukrainian]

3. Biblical idioms and sayings with origins explained. Web site. URL : https://improving-your-english.com/vocabulary/ idioms/bible-idioms/ [in English]

4. Engblog. Dlya izuchayuschih angliyskiy yazyik [For the learners of English]. Web site. URL: https://engblog.ru/origins-of-idioms [in Russian]

5. Greeker than the Greeks. Web site. URL : https://greekerthanthegreeks.com/2019/04/20-everyday-english-phrasessayings-and-idioms-with-greek-origins.html [in English]

6. McCarthy M. Cambridge International Dictionary of Idioms. Cambridge University Press. 2002. 604 p. [in English] 